leo Antarctic ice streams were underlain by weak sediments is indicative of a dynamic, fast-flowing ice sheet at the LGM, much like it is today in West Antarctica, allowing rapid ice-sheet responses to sea level and ocean temperature changes.

\section{Future activities}

Although our appreciation of Antarctic history has improved dramatically over the past decade, there is still much to learn. Significant questions exist about the evolution of Antarctic landscape, both above and below the ice cover; its connection with ice-sheet development; past and present large-scale ice-sheet dynamics and stability; the role of sub-glacial water in the ice-sheet system; and the influence of ice-sheet evolution on Antarctic biology. In 2004, the Scientific Committee on Ant- arctic Research (SCAR) recognised the importance of understanding past changes in Antarctica with the establishment of its Antarctic Climate Evolution (ACE) scientific research program. This program, in conjunction with other SCAR program's (SALE - Subglacial Antarctic Lake Environments; AGCS - Antarctica in the Global Climate System; and EBA - Evolution and Biodiversity in Antarctica), aims to further integrate numerical models with geological data, in order to understand the processes responsible for the growth and decay of large ice sheets and to comprehend the global significance of such changes.

\section{Acknowledgements}

We thank the committee and members of the ACE program (www.ace.scar.org) for helpful input and advice.

\section{References}

Anderson, J.B., Shipp, S.S., Lowe, A.L., Wellner, J.S. and Mosola, A.B., 2002: The Antarctic ice sheet during the last glacial maximum and its subsequent retreat history: a review, Quaternary Science Reviews, 21: 49-70.

DeConto, R.M. and Pollard, D., 2003: Rapid Cenozoic glaciation of Antarctica induced by declining atmospheric $\mathrm{CO}_{2}$, Nature, $\mathbf{4 2 1}$ 245-249.

Naish, T.R., Woolfe, K.J., Barrett, P.J., Wilson, G.S. and 29 others, 2001 Orbitally induced oscillations in the East Antarctic ice sheet at the Oligocene-Miocene boundary, Nature, 413: 719-723.

ó Cofaigh, C., Pudsey, C.J., Dowdeswell J.A. and Morris, P., 2002: Evolution of subglacial bedforms along a paleo-ice stream, Antarctic Peninsula continental shelf, Geophysical Research Letters, 29 10.1029/2001GL014488.

Taylor, J., Siegert, M.J., Payne, A.J., Hambrey, M.J. O'Brien, PE., Cooper, A.K. and Leitchenkov, G., 2004: Topographic controls on postOligocene changes in ice-sheet dynamics, Prydz Bay region, East Antarctica, Geology, 32: 197-200.

For full references please consult:

www.pages-igbp.org/products/newsletter/ref2007_2.html

\title{
Antarctic ice cores
}

\section{ERIC WolfF ${ }^{1}$ AND EdWARd Brook}

'British Antarctic Survey, Cambridge, UK; ewwo@bas.ac.uk; ²Deptartment of Geosciences, Oregon State University, Corvallis, USA

Terrestrial and marine paleoclimate records are very sparse in the southern hemisphere, particularly at high latitudes. However, this is where ice cores come into their own. Antarctic ice cores provide a firm and wellresolved anchor for our understanding of how climate has evolved over $800 \mathrm{kyr}$, and provide climate information for assessing how the Antarctic Ice Sheet may have varied over the same period. They are also the best archive for determining the history of greenhouse gas concentrations and offer unique data on other important forcings, such as volcanic aerosol and solar.

\section{Characteristics of Antarctic ice cores}

Almost the whole of the Antarctic ice sheet fulfils the basic requirements for good ice core records, namely that snow is laid down in regular layers without significant loss or percolation by melting. In near coastal areas, relatively high snow accumulation rates allow the collection of records for which annual layer counting is possible. This is the area of choice for wellresolved and precisely dated records of recent centuries. In central regions of the Antarctic plateau, the ice is very thick $(\sim 3$ $\mathrm{km}$ ) but the snow accumulation rate may be as low as $2 \mathrm{~cm}$ water equivalent. It is in this region that records extending back over hundreds of thousands of years can be found, although the dating is necessarily less precise.

The water isotopes in the ice act as a good proxy of Antarctic temperature and also provide information on conditions over the ocean (the source of the water vapor). Due to the low impurity content of the ice, Antarctic cores are well suited to analysis of trace gases, and the chemical content provides information about environmental conditions in the Southern Ocean and other southern continents.

\section{Recent centuries}

As atmospheric measurements of greenhouse gases have only been carried out routinely for, at most, a few decades, ice cores have for some time been relied upon to show how greenhouse gas concentra-

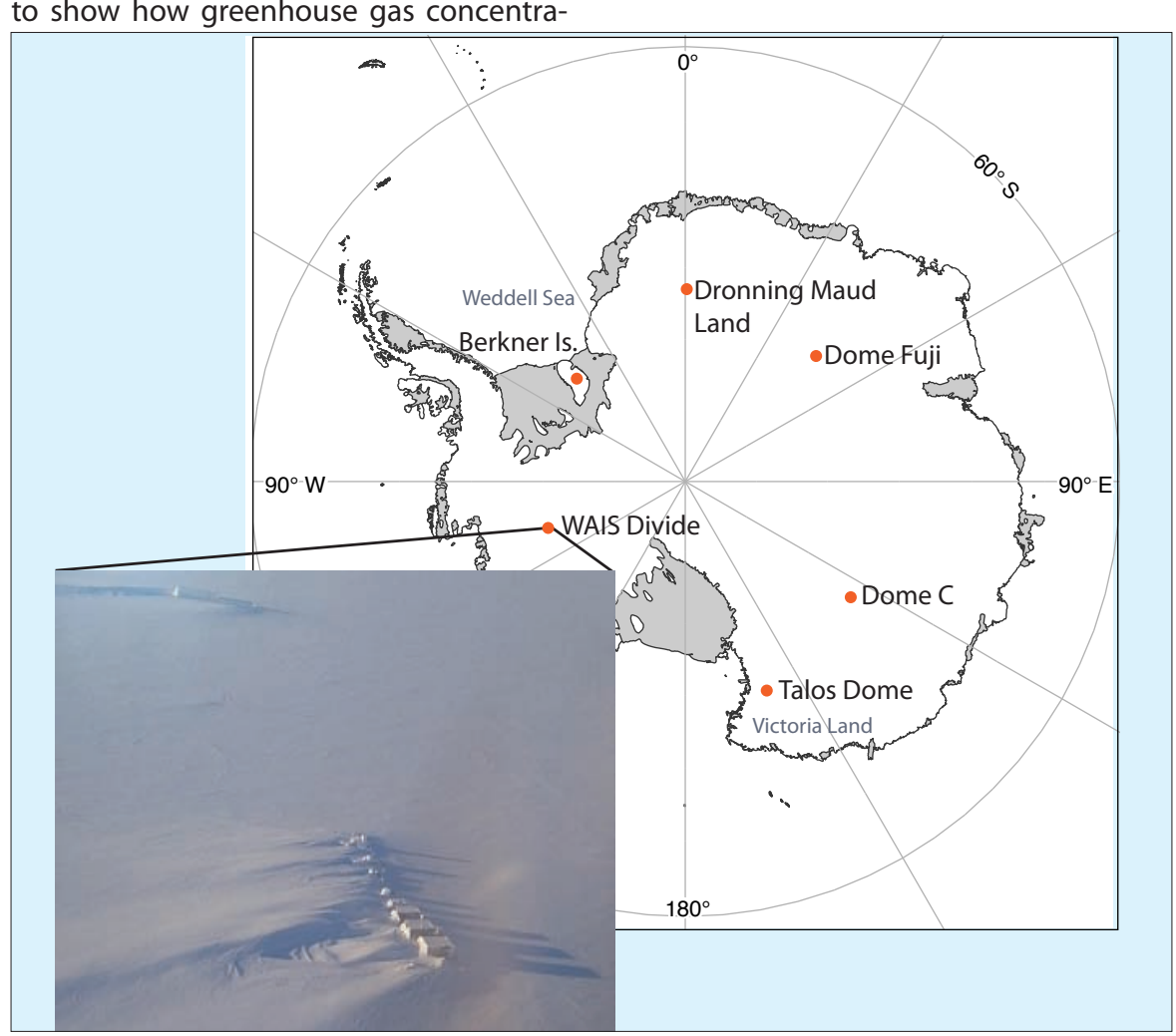

Figure 1: Map of cores and locations mentioned in text. Inset: photo of WAIS Divide site, with camp in center and drilling site top left corner (E. Brook). tions increased during the past two centuries, and how they varied in the preceding period. A new study (MacFarling Meure et al., 2006) has extended the period of highresolution to $2 \mathrm{kyr}$, expanded the high-resolution work from $\mathrm{CO}_{2}$ and $\mathrm{CH}_{4}$ to include $\mathrm{N}_{2} \mathrm{O}$, and filled in gaps in the previous records. Together with the existing data and other data from sites with lower-resolution that confirm most of the details, this work provides a definitive account of greenhouse gas variability and trend; it is indeed 




Figure 2: Estimated difference in Dome C temperature, compared to today, over the last $810 \mathrm{kyr}$, calculated from deuterium data. Figure based on data in Jouzel et al. (2007).

much quoted in the recent IPCC 4th assessment report.

Other studies of the recent past have moved on from interpreting single records and focussed on combining sets of ice core records, in order to establish the reliable common signal and discard the "noise" in the proxy (e.g., Schneider et al., 2006). This kind of work will make ice core data more suitable for inclusion in multi-proxy reconstructions of southern hemisphere climate from different archives. It is now becoming more common to compare data with atmospheric reanalyses to establish relationships and calibrations that might be applied to earlier periods. Both features of the pressure field (for major ionic species) and sea-ice extent (for methanesulfonic acid (Abram et al., 2007)) have been used as targets for reconstruction.

\section{Glacial-interglacial cycles}

Probably the biggest excitement in the ice core community in the last few years has come from analyzing the oldest parts of three newly completed deep ice cores: the EPICA cores at Dome $\mathrm{C}$ and Dronning Maud Land, and the Dome Fuji core (Fig. 1). Much of the new science coming from these cores has relied on advances in dating the cores. The discovery in the Dome $C$ core of signals (in the ${ }^{10} \mathrm{Be}$ concentration) of the Brunhes-Matuyama magnetic reversal some $780 \mathrm{kyr}$ ago gives a very firm anchor to the deepest part of the record. An entire journal special issue (www.climpast.net/special_issue7.html) devoted to the dating and synchronization of the two EPICA cores shows that this subject is now being treated very seriously; the new EDC3 age scale for Dome C (Parrenin et al., 2007) is much more compatible with the best marine age scales (Lisiecki and Raymo, 2005), making combined studies much more feasible. Use of $\mathrm{N}_{2} / \mathrm{O}_{2}$ in the gases in ice (Kawamura et al., 2007), which appears to be related to local insolation, has opened up the possibility of absolute age scales that are accurate enough to allow reliable conclusions to be made regarding the phasing of insolation forcing and climate changes.

The water isotope analysis of the Dome $C$ core has now been completed at high resolution and reveals the temperature history of Antarctica back to just beyond 800 kyr (Fig. 2) (Jouzel et al., 2007), confirming that glacial cycles recurred at 100 kyr intervals throughout but with different styles and amplitudes. It has now been shown that every Dansgaard-Oeschger (DO) event in the northern hemisphere appears to have a subdued counterpart in the south (EPICA Community Members, 2006); further improvements in the definition of the phasing between northern and southern records are still needed but this result is highly suggestive of ocean heat transport as the main player in these changes. The pattern of climate variability seen in each glacial cycle strongly suggests that DO events occurred in earlier glacial periods (Jouzel et al., 2007). Chemical records (Wolff et al., 2006) covering the EPICA Dome $C$ period open up the possibility of assessing the causes of climate change through a range of environmental parameters, since the chemical signals provide information about, for example, South American climate, aerosol concentrations, inputs for iron fertilization, sea-ice extent and marine productivity.

\section{Ongoing projects and future plans}

The brief summary above omits numerous interesting data sets, analytical developments and interpretative improvements. Further progress will also come from a number of projects that are currently un- derway. The US West Antarctic Ice Sheet (WAIS) Divide ice core (Fig. 1) is intended to provide a high-resolution (comparable to Greenland) record of the last glacial cycle in West Antarctica; this should be a particularly good core for assessing the phasing between north and south and between climate and $\mathrm{CO}_{2}$. The camp construction and pilot hole were completed in 2006/07 and the core should be drilled in the next 3 seasons. Meanwhile, other sites have progressed and contribute to a spatial network of cores covering a similar period. At Berkner Island (Fig. 1), sand was collected from the cold base of the ice sheet in 2005/06 and $948 \mathrm{~m}$ of ice is now being processed. This core is revealing both the climate and the ice sheet configuration in the Weddell Sea sector of Antarctica. Meanwhile, drilling is continuing at Talos Dome in Victoria Land, from the depth of $1300 \mathrm{~m}$ reached in 2006/07 (Fig. 1).

For the future, IPICS (International Partnerships in Ice Core Sciences; www. pages-igbp.org/science/initiatives/ipics/ whitepapers.html) has defined a series of 4 priority science projects and associated technical challenges. Of the 3 projects including Antarctica, one has the ambitious aim of reaching still older ice and assessing the climate and trace gas content during $40 \mathrm{kyr}$ climate cycles that preceded the mid-Pleistocene revolution. Other projects aim to construct a network of cores covering the last $40 \mathrm{kyr}$, to assess the spatial pattern of change during rapid climate events, and a network of cores representing $2 \mathrm{kyr}$ to contribute Antarctic data to climate reconstructions.

\section{References}

EPICA Community Members, 2006: One-to-one hemispheric coupling of millennial polar climate variability during the last glacial, Nature, 444: 195-198

Jouzel, J., Masson-Delmotte, V., Cattani, 0., Dreyfus, G., Falourd, S. Hoffmann, G., Nouet, J., Barnola, J.M., Chappellaz, J., Fischer, H., Gallet, J.C., Johnsen, S., Leuenberger, M., Loulergue, L., Luethi, D., Oerter, H., Parrenin, F., Raisbeck, G., Raynaud, D., Schwander, J.s Spahni, R., Souchez, R., Selmo, E., Schilt, A., Steffensen, J.P. Stenni, B., Stauffer, B., Stocker, T., Tison, J.-L., Werner, M. and Wolff, E. W., 2007: Orbital and millennial Antarctic climate variability over the last 800000 years, Science, 317: 793-796.

Kawamura, K., Parrenin, F., Lisiecki, L., Uemura, R., Vimeux, F., Severinghaus, J. P., Hutterli, M.A., Nakazawa, T., Aoki, S., Jouzel, J., Raymo, M.E., Matsumoto, K., Nakata, H., Motoyama, H., Fujita, S., Azuma, K., Fujii, Y. and Watanabe, 0., 2007: Northern Hemisphere forcing of climatic cycles over the past 360,000 years implied by accurately dated Antarctic ice cores, Nature, 448: doi: 10.1038/ nature06015

MacFarling Meure, C., Etheridge, D., Trudinger, C., Steele, P., Langenfelds, R., van Ommen, T., Smith, A. and Elkins, J., 2006: Law Dome CO $\mathrm{CH}$ and $\mathrm{N}_{2} 0$ ice core records extended to 2000 years BP, Geophysical Research Letters, 33: L14810, doi:10.1029/2006GL026152.

Parrenin, F., Barnola, J.M., Beer, J., Blunier, T., Castellano, E., Chappellaz, J., Dreyfus, G., Fischer, H., Fujita, S., Jouzel, J., Kawamura, K. Lemieux, B., Loulergue, L., Masson-Delmotte, V., Narcisi, B., Petit, J.R., Raisbeck, G., Raynaud, D., Ruth, U., Schwander, J., Severi, M., Spahni, R., Steffensen, J.P., Svensson, A., Udisti, R., Waelbroeck, C. and Wolff, E.W., 2007: The EDC3 age scale for the EPICA Dome Cice core, Climate of the Past Discussions, 3: 575-606. 